DOI: 10.46340/eppd.2021.8.2.9

\author{
Alona Hnatovska, PhD in Law \\ ORCID ID: https://orcid.org/0000-0001-7171-3209 \\ Chernivtsi Law Institute, National University "Odessa Law Academy", Ukraine \\ Anna Marushak, PhD in Law \\ ORCID ID: https://orcid.org/0000-0002-4611-4906 \\ Chernivtsi Law Institute, National University "Odessa Law Academy", Ukraine
}

\title{
CONCEPTUAL PRINCIPLES OF E-DEMOCRACY AND E-GOVERNANCE IN UKRAINE
}

\author{
Альона Гнатовська, к. ю. н. \\ Анна Марущак, к. ю. н. \\ Чернівецький юридичний інститут Національного Університету «Одеська \\ юридична академія», Україна
}

\section{КОНЦЕПТУАЛЬНІ ЗАСАДИ ЕЛЕКТРОННОЇ ДЕМОКРАТІЇ ТА ЕЛЕКТРОННОГО УРЯДУВАННЯ В УКРАЇНІ}

\begin{abstract}
The article is devoted to the current state of digital transformation of Ukrainian society. Given the global introduction of computer information technology in the lives of both the state and the average citizen, it is important to describe the concept and content of e-democracy. The transition to e-democracy is impossible without the use of e-government. In this regard, it is important to define the concept of e-government, its features and aspects of its understanding. The study shows a steady global trend towards increasing the level of e-government. A strong, efficient and secure electronic system must guarantee the quality of public administration. The article outlines the obstacles that have already been overcome as a result of high-quality management diligence, as well as those problems that still need to be addressed.

The conceptual bases of scientific interpretation of the concept of "electronic democracy" are defined. The legal definition of e-democracy in ukrainian legislation is analyzed. Examples of countries with the most successful and effective implementation and use of e-government and e-democracy are given. The normative legal acts regulating the relations connected with e-government and edemocracy are considered. The basic rights of a citizen are described, the realization of which is aimed at e-democracy and e-government. The problem of lack of normative basis for introduction of electronic voting in Ukraine is outlined. The modern state reforms carried out in order to increase the degree of digitalization of public services are analyzed. The main tasks of e-government are identified. Taking into account the statistical data, it is concluded that there is a steady global trend towards increasing the level of development of e-government and e-democracy.
\end{abstract}

Keywords: e-democracy, e-government, computer information technology, digitalization of society, electronic form of public administration.

Постановка проблеми. Цифровізація у сфері державного управління наразі є важливою темою для наукових досліджень. Це наслідок всеохоплюючого впливу Інтернету та соціальних медіа на суспільство, які набирають все більшої популярності не лише у міжособистісних відносинах, а i у сферах державного управління. Варто сказати, що використання електронних ресурсів для різних аспектів демократії та публічного адміністрування стає не лише допоміжним ресурсом, а і набуває ознак певної необхідності. Неодноразово у наукових колах підкреслювались взаємодія та взаємовплив електронного урядування та електронної демократії, зокрема вплив електронного уряду на демократичний процес. Електронна демократія також концептуально пов'язана з електронним урядом, але, водночас, потрібно розуміти, що це не тотожні поняття, і слід відрізняти ці категорії одну від одної. 
Метою статті $€$ розкриття проблематики впровадження повноцінного та якісного електронного урядування на шляху до електронної демократії.

Виклад основного матеріалу. Сучасні тенденції свідчать, що традиційні зв'язки між громадянами та представниками політичних сил слабшають. Водночас, відносини між обраними представниками, громадянами, громадянським суспільством та політичною владою розвиваються, тому значного поширення набувають електронні інструменти, включаючи Інтернет, веб-сайти, соціальні мережі. Вони можуть допомогти мобілізувати виборців, збільшити участь громадян у різних способах покращення надання державних послуг, сприяння інноваціям та економічному зростанню, зрештою навіть зміцнити демократію.

На сьогодні найяскравішим прикладом успішного існування електронної демократії є Естонія. Країна почала свій шлях до «цифрового суспільства» ще понад 20 років тому, в 1997 році була започаткована система електронного урядування, за допомогою якої здійснювалось надання державних послуг через мережу Інтернет. 3 часом можливості користування Інтернетом значно розширились серед суспільства, а, відповідно, разом із ними набув більшого використання і увесь спектр надання держаних послуг за допомогою інформаційних комп’ютерних технологій. Естонія на законодавчому рівні запровадила можливість існування електронних податків, електронну охорону здоров'я і електронне голосування. У 2007 році Естонія стала першою у світовій практиці країною, що забезпечила своїм громадянам можливість реалізувати їхнє виборче право шляхом голосування через Інтернет на парламентських виборах. У 2017 році журнал Wired назвав країну «найдосконалішим цифровим суспільством у світі». Поряд з Естонією стрімкого розвитку електронне голосування набуває і у Великобританії, Швейцарії та Франції.

Незважаючи на досить довгу історію виникнення різноманітних концепцій та ідей електронної демократії, у сучасному науковому просторі не існує загальноприйнятої узгодженої позиції щодо визначення даного терміну. Серед численних концепцій можна виділити як визначення, що мають ознаки нормативного характеру, так і наукового. I кожне з них так чи інакше акцентує увагу на певній особливості електронної демократії.

У загальному, електронна демократія, (е-демократія) - це використання інформаційних та комунікаційних технологій для посилення, а в деяких випадках і для заміни представницької демократії.

Науковці, об’єктом досліджень яких стала електронна демократія мають різні точки зору щодо цього явища, але більшість 3 них поділяють єдине переконання, що в сучасних ліберальнодемократичних державах дефіцит часу, ухилення громади від участі у важливих загальнодержавних процесах та відсутність можливостей для обговорення політики можуть бути подолані за допомогою нових формами Інтернет-комунікацій.

Н.В. Грицяк та С.Г. Соловйов, автори навчального посібника «Електронна демократія», розглядають даний термін у широкому та вузькому значеннях. У першому випадку науковці розглядають електронну демократію як застосування інформаційно-комунікаційних технологій для забезпечення (електронного супроводу) прав громадян. А широке розуміння електронної демократії передбачає залучення громади за допомогою сучасних інформаційних технологій до вирішення різноманітних суспільно-політичних завдань ${ }^{1}$. Вузьке розуміння охоплює більше технологічну сторону, за допомогою якої громадяни можуть подати різного роду заяви, звернення, запити до органів влади задля отримання певної довідки чи інформації. Такі дії здійснюються громадянами у межах реалізації їхніх прав, зокрема, право на направлення індивідуальних або колективних звернень, що визначене ст. 40 Конституції України: усі мають право направляти індивідуальні чи колективні письмові звернення або особисто звертатися до органів державної влади, органів місцевого самоврядування та посадових і службових осіб цих органів, що зобов'язані розглянути звернення і дати обгрунтовану відповідь у встановлений законом строк². Тобто фактично це заміна письмової форми здійснення певних дій на електронну. Як приклад електронної демократії у широкому розумінні автори наводять інтерактивну участь жителів у засіданні місцевої ради, коли засідання місцевої ради транслюється в інтернеті в режимі он-лайн, і під час цього кожний, хто виявляє відповідне бажання, може висловити своє ставлення до рішень ради, виступів депутатів, $\mathrm{i}$ відтак - вплинути на позицію органу влади.

\footnotetext{
${ }^{1}$ Грицяк, Н. В., Соловйов, С. Г. (2015). Електронна демократія. Київ: НАДУ.

${ }^{2}$ Конститучія Украйни, 1996 (Верховна Рада України). Відомості Верховної Ради Украӥни, $30,141$.
} 
Зарубіжні науковці В. Дрожжинов та А. Штрик, е-демократію розглядають як використання інформаційно-комунікаційних технологій та інформаційної інфраструктури для розвитку й посилення демократичних інститутів і розширення участі громадян у суспільній та політичній діяльності ${ }^{1}$.

Схоже визначення пропонує і О.А. Баранов: електронна демократія - це демократія, для якої значно підвищується ефективність демократичних інститутів, демократичних процесів та поширення демократичних цінностей за умови застосування різноманітних інструментів, що базуються на максимальному використанні інформаційних комп'ютерних технологій ${ }^{2}$.

На думку В.К. Лур'є «Е-демократія - це інструмент підвищення якості управлінських рішень, що стосуються як кожного окремого учасника політичного процесу, так і суспільства в цілому» ${ }^{3}$.

Вітчизняне законодавство визначає електронну демократію як форму суспільних відносин, за якої громадяни та організації залучаються до державотворення та державного управління, а також до місцевого самоврядування шляхом широкого застосування інформаційно-комунікаційних технологій в демократичних процесах, що дає змогу: посилити участь, ініціативність та залучення громадян на загальнодержавному, регіональному та місцевому рівні до публічного життя; поліпшити прозорість процесу прийняття рішень, а також підзвітність демократичних інститутів; поліпшити зворотну реакцію суб'єктів владних повноважень на звернення громадян; сприяти публічним дискусіям та привертати увагу громадян до процесу прийняття рішень ${ }^{4}$. Таке визначення було встановлене розпорядженням КМУ «Про схвалення Концепції розвитку електронної демократії в Україні та плану заходів щодо іiі реалізації» у 2017 р. і значно розширило попереднє нормативне визначення 2013 року, яке містилось у іншому розпорядженні КМУ «Про схвалення Стратегії розвитку інформаційного суспільства в Україні».

3 наведеного вище визначення видно, що зміст визначення електронної демократії, запропонований законодавцем, спрямований більше на розширення можливостей для налагодження «змістовного діалогу» між громадянами та органами державної влади, тобто залучення громадськості до використання електронних ресурсів задля реалізації своїх конституційних прав, встановлених ст.40 Конституції України. У контексті електронної демократії така реалізація можлива через електронні петиції та електронні консультації. Але найяскравішим проявом демократії є саме ії пряма форма - вибори. А щодо проведення електронних виборів в Україні, поки не має жодних законодавчих передумов. Хоча цифрові технології стають дедалі важливішими у всіх сферах життя, вони ще не відіграють значної ролі у політичних процесах України. Україна ще повинна пройти досить тривалий шлях для забезпечення можливостей проведення електронного голосування.

Хоча, варто зазначити, що спроби реалізувати електронне голосування на практиці все ж таки були. У парламенті, починаючи з 2011 року були зареєстровані декілька законопроектів, метою яких було вдосконалення системи голосування з урахуванням світового досвіду застосування новітніх електронних та комунікаційних технологій: законопроект №8656 «Про концепцію запровадження системи електронного голосування», №10129 «Про внесення змін до деяких законів України щодо забезпечення виборчих прав громадян України шляхом запровадження на виборах голосування поштою та інтернет-голосування». Проте усі вони були відкликані або зняті з розгляду.

Однією із основних цілей електронної демократії є посилена інтеграція громадян у політичну сферу держави. Підключення до Інтернету дає змогу більшій кількості людей брати участь у багатьох дискусіях, які раніше були недоступні для громадськості. Цифровізація демократії участі спрямована на підвищення прозорості та легітимності політичних систем шляхом демократичного залучення. Зміст електронної демократії полягає у сприянні просуванню демократії за допомогою цифрових засобів, забезпечуючи прозорість політичних процесів. Це своєрідний засіб сприяння ефективній взаємодії політики, уряду та процесу прийняття рішень.

\footnotetext{
${ }^{1}$ Дрожжинов, В. И., Штрик, А.А. (2003). Электронная демократия и поддерживающие ее технологии. Технологии информационного общества. Интернет и современное общество: тр. VI Всеросс. объединенной конференции (3-6 ноября 2003, г.Санкт-Петербург), 101-110.

2 Баранов, О. А. (2017). Правові проблеми "електронної демократії". Інформація і право, 1, 28-38.

3 Лур’є, В. К. (2017). Концепція електронної демократії. Вісник Національного університету Юридична академія Украӥни імені Ярослава Мудрого. Серія: Політологія, 2, 210-216.

${ }^{4}$ Про схвалення Концепції розвитку електронної демократії в Україні та плану заходів щзодо їі реалізації, 2017 (Кабінет Міністрів України). Офіиійний сайт Верховної Ради Украӥни <https://zakon.rada.gov.ua/laws/show/ 797-2017-\%D1\%80\#Техt> (2021, лютий, 18).
} 
Державному апарату в демократичній політичній системі доводиться під тиском суспільства бути публічною організацією, відкритою до діалогу з населенням. Така вимушена публічна поведінка в умовах демократії призводить до підвищення ролі інформаційного забезпечення публічного адміністрування, що забезпечує зворотній зв'язок органів влади з суспільством.

Україна активно впроваджує у життя ідею «держава у смартфоні». Зокрема, із цією метою у вересні 2019 року було створене Міністерство цифрової трансформації ${ }^{1}$. Одним із основних здобутків Кабінету Міністрів України та Міністерства цифрової трансформації $є$ створення застосунку «Дія» (Держава і Я), що надає низку адміністративних послуг онлайн ${ }^{2}$.

Саме встановлення і підтримання такого зв'язку виступає одним з основних найважливіших напрямків роботи всієї системи публічного адміністрування в демократичній державі, яка реалізує вимоги щодо прозорості та публічності їх діяльності. Проте інформаційне суспільство є зовсім іншим видом демократії, ніж іï традиційний механізм. Відповідно це й інший рівень інформаційного забезпечення прийняття рішень в системі державної влади.

Впровадження електронного урядування пов'язано, перш за все, зі структурними змінами в системі публічного адміністрування, а саме з перетворенням обсягу, характеру та спрямованості функцій органів виконавчої влади, а також впровадженням електронних адміністративних регламентів діяльності.

На шляху до якісного та результативного застосування електронного урядування в Україні було поставлено та частково вирішено ряд завдань:

a) створено кадрове забезпечення системи управління «електронним урядом», яке відповідає сучасним стандартам публічного адміністрування;

б) забезпечено доступ до прозорої, відкритої та доступної системи механізмів державноприватного партнерства, відповідно до якої здійснюється регулювання відносин між органами публічної влади, юридичними або фізичними особами, їх об'єднаннями;

в) здійснюється популяризація доступності державних послуг;

г) моніторинг законодавства та правозастосування при використанні інформаційного потенціалу в публічному адмініструванні;

д) застосування системного підходу в процесі впровадження електронного урядування.

Поняття «електронний уряд» у повній мірі неможливо розглянути, не визначивши його ознаки:

- зменшення сфери адміністративного розсуду при здійсненні державних функцій і наданні державних послуг, зниження ролі фактору суб'єктивності кадрового персоналу в процесі підготовки і прийнятті адміністративних актів (рішень);

- посилення дії принципу оперативності при підготовці та прийнятті управлінських рішень за рахунок використання електронних інформаційних ресурсів у режимі реального часу, а також підвищення ефективності адміністративної нормотворчості в цілому;

- формування належного рівня прозорості в процесі надання державних послуг за рахунок автоматичного сповіщення одержувачів послуг або контролюючого органу про процес їх реалізації, а також створення єдиної системи моніторингу в процесі використання інформаційних технологій у публічному адмініструванні (як найбільш важливої умови ефективності адміністративно-правового регулювання відносин в області публічного управління);

- суттєве зменшення паперового документообігу;

- створення юридичного механізму притягнення до відповідальності посадових осіб органів виконавчої влади за неналежне дотримання вимог нормативних правових актів при виконанні окремих адміністративних процедур і адміністративних дій за рахунок використання автоматичного контролю за їх діями.

Електронне урядування представляється в таких аспектах:

-як засіб, що забезпечує державі перспективу і необхідний рівень конкурентоспроможності серед інститутів суспільства інформаційної епохи;

-як модель діяльності держави в умовах «нової економіки» і фактор становлення «нової економіки»;

\footnotetext{
${ }^{1}$ Положення про Міністерство иифрової трансформації Украӥни, 2019 (Кабінет Міністрів України). Офіційний сайт Верховної Ради Украӥни < https://zakon.rada.gov.ua/laws/show/856-2019-\%D0\%BF\#Text> (2021, лютий, 18)

${ }^{2}$ Everlegal (2020). Україна піднялася на 13 місие у рейтингу готовності до запровадження електронного уряду <https://everlegal.ua/ukrayina-pidnyalasya-na-13-mists-u-reytyngu-gotovnosti-do-zaprovadzhennya-elektronnogo-uryadu> (2021, лютий, 18).
} 
- як спосіб підтримки економічної, правової, політичної, адміністративної та цивільної єдності країни та інструмент забезпечення єдності і нерозривності публічного адміністрування;

- як нова організаційно-управлінська культура державного апарату;

-як інструмент модернізації системи державного управління і метод подолання «інформаційного розриву» між рівнями і гілками державної влади, засіб забезпечення гнучкості і адаптивності системи публічного адміністрування.

Суспільству потрібен чіткий, простий, ясний і доступний для громадян порядок, що надає високий ступінь прозорості, стабільності та гарантованості всіх життєвих процесів, а також оптимальний обсяг нормативно-правових актів за рахунок збільшення спільності правових приписів, оптимального механізму державного управління з метою усунення дублювання функцій органів публічної влади і точного встановлення обсягу їх компетенції. Електронний уряд закладає ідею комплексного перетворення принципів організації адміністрування державою. Хоча, за фактом, формування електронного уряду часто зводиться лише до рівня впровадження інформаційних технологій.

У зв’язку з цим у звіті ООН «Електронний уряд на роздоріжжі» підкреслено, що впровадження «електронного уряду» аж ніяк не означає, що нові інформаційні технології в подальшому замінять державних службовців ${ }^{1}$.

Його сенс полягає в тому, що вся діяльність органів публічного адміністрування повинна спиратися на сильну, ефективну і безпечну електронну систему як у внутрішній діяльності, так і при взаємодії з громадянами. Це потрібно для того, щоб бази даних органів виконавчої влади різного рівня були сумісні і мали можливість обмінюватися інформацією, а для зручності громадян діяв сервіс, при якому вони, не залишаючи місця свого перебування, оформлюють необхідні документи.

Дослідження «E-Government Survey 2020» показує стійку глобальну тенденцію до підвищення рівня розвитку електронного урядування. Дослідження поділяє держави на 4 групи: із низьким, середнім, високим та дуже високим рівнями розвитку електронного уряду. Україна належить до групи країн із високим рівнем розвитку, іiі результати найбільш наближені до показників Вірменії та Азербайджану².

Традиційно, у рейтингу лідирують Данія, Південна Корея, Естонія, Фінляндія та Австралія. Найгірші результати на 2020 рік показали Судан, Ерітрея та Центральноафриканська Республіка.

Висновки. Впровадження практики використання електронних способів управління дало поштовх виникненню нових адміністративних механізм в урядах усього світу, покращуючи цим ефективність, прозорість та підзвітність.

Політика української держави орієнтована на активне впровадження цифрових потужностей в життя народу, незважаючи на відсутність цифрової інфраструктури, стійких платформ електронного уряду, обмежені ресурси для реалізації та фактичне перебування країни у стані війни.

Прямуючи на шляху до електронної демократії, потрібно керуватися довгостроковими та багатоаспектними задачами, які необхідно поетапно вирішувати задля досягнення бажаних цілей. Це надасть змогу одночасно вдосконалити практику державного управління та пожвавити демократію.

Про дійсну електронну демократію та якісне електронне урядування можна говорити лише після їх випробування часом та можливість подолання або пом'якшення за їх допомогою кризових ситуацій.

Цифрова трансформація $є$ важливою частиною сталого розвитку України. Вона включає у себе як соціальний, так і політичний контекст, що одночасно є і передумовами виникнення нових форм та методів здійснення державного управління. Відкритим залишається питання легітимації даних інформаційно-комунікаційних технологій.

\section{References:}

1. Baranov, O. A. (2017). Pravovi problemy "elektronnoi demokratii" [Legal problems of "e-democracy"]. Informatsiia i pravo [information and law], 1, 28-38. [in Ukrainian].

2. Drozhzhinov, V. I., Shtrik, A. A. (2003). Elektronnaia demokratiia i podderzhivaiushchie ee tekhnologii [E-democracy and supporting technologies]. Tekhnologii informatcionnogo obshchestva. Internet i sovremennoe

\footnotetext{
${ }^{1} \mathrm{OOH} \mathrm{(2018).} \mathrm{Обзоры} \mathrm{ООН} \mathrm{по} \mathrm{электронному} \mathrm{правительству}$

<https://publicadministration.un.org/ru/Research/UN-e-Government-Surveys> (2021, лютий, 18).

${ }^{2}$ E-Government Survey (2020). Digital Government in the Decade of Action for Sustainable Development

<https://publicadministration.un.org/ egovkb/Portals/ egovkb/Documents/un/2020-Survey> (2021, лютий, 18).
} 
obshchestvo : tr. VI Vseross. obedinennoi konferentcii (3-6 noiabria 2003, g.Sankt-Peterburg) [Information society technologies. Internet and modern society: tr. VI All-Russian. Joint Conference (November 3-6, 2003, St. Petersburg)], 101-110. [in Russian].

3. E-Government Survey (2020). Digital Government in the Decade of Action for Sustainable Development <https://publicadministration.un.org/ egovkb/Portals/egovkb/Documents/un/2020-Survey> (2021, February, 18). [in English].

4. Gricjak, N. V., Solovjov, S. G. (2015). Elektronna demokratija [E-democracy]. Kï̈v: NADU. [in Ukrainian].

5. Konstitucija Ukraini, 1996 (Verhovna Rada Ukraini) [Constitution of Ukraine, 1996 (Verkhovna Rada of Ukraine)]. Vidomosti Verhovnoyi Radi Ukraini [News of the Verkhovna Rada of Ukraine], 30, 141. [in Ukrainian].

6. Lurie, V. K. (2017). Koncepcija elektronnoï demokratiï [Concept of e-democracy]. Visnik Nacionalnoho universitetu Juridichna akademija Ukrayni imeni Jaroslava Mudroho. Serija: Politolohija [Bulletin of the National University Yaroslav the Wise Law Academy of Ukraine. Series: Political Science], 2, 210-216. [in Ukrainian].

7. OON (2018) [UN (2018)]. Obzory OON po jelektronnomu pravitelstvu [UN Surveys on e-government]. <https://publicadministration.un.org/ru/Research/UN-e-Government-Surveys> (2021, February, 18). [in Russian].

8. Polozhennia pro Ministerstvo tsyfrovoi transformatsii Ukrainy, 2019 (Kabinet Ministriv Ukrainy) [Principle about the Ministry of Digital Transformation of Ukraine, 2019 (Cabinet of Ministers of Ukraine)]. Ofitsiynyy sayt Verkhovnoyi Rady Ukrayiny [Official site of the Verkhovna Rada of Ukraine] <https://zakon.rada.gov.ua/laws/show/856-2019-\%D0\%BF\#Text> (2021, February, 18). [in Ukrainian].

9. Pro skhvalennia Kontseptsii rozvytku elektronnoi demokratii v Ukraini ta planu zakhodiv shchodo yii realizatsii, 2017 (Kabinet Ministriv Ukrayiny) [Order approving the Concept for the Development of Electronic Democracy in Ukraine and the Action Plan for its Implementation, 2017 (Cabinet of Ministers of Ukraine)]. Ofitsiynyy sayt Verkhovnoyi Rady Ukrayiny [Official site of the Verkhovna Rada of Ukraine] <https://zakon.rada.gov.ua/laws/show/797-2017-\%D1\%80\#Text> (2021, February, 18). [in Ukrainian].

10. Everlegal (2020). Ukraina pidnialasia na 13 mistse u reitynhu hotovnosti do zaprovadzhennia elektronnoho uriadu [Ukraine has risen to 13th place in the ranking of readiness for the introduction of e-government] <https://everlegal.ua/ukrayina-pidnyalasya-na-13-mists-u-reytyngu-gotovnosti-do-zaprovadzhennya-elektronnogo-uryadu> (2021, February, 18). [in Ukrainian]. 